\title{
ASSESSMENT OF DEFICIT IRRIGATION AND FOLIAR APPLICATION OF SALICYLIC ACID AND POTASSIUM SILICATE ON PERFORMANCE OF DRIP - IRRIGATED ONION CROP IN SANDY SOILS
}

\author{
A.E. Abd El-All (1), A. K. Abdelhalim ${ }^{(2)}$ and A. El-Namas ${ }^{(3)}$ \\ ${ }^{(1)}$ Calcareous and Sand Soil Research Department, ARC, Giza, Egypt \\ ${ }^{(2)}$ Water Requirements and Field Irrigation Research Department, ARC, Giza, Egypt \\ (3) Soil and water department, Faculty of Agriculture, Alex. University, Alexandria, Egypt
}

Received: Dec. 6, 2016

Accepted: Dec. 31,2016

ABSTRACT: The present experiment was conducted during 2011/2012 and 2012/2103 winter seasons to study the effect of irrigation regimes e.g. 60, 80 and 100\% ETo and foliar application of Potassium Silicate (PS) and Salicylic Acid(SA) in 250 and $400 \mathrm{mgL}^{-1}$ for both and interactions. The adopted treatments were assessed a split - plot design with 3 replicates. The irrigation regimes were represented inthe main plots, whereas foliar application of $P S$ and $S A$ treatments were allocated to the split plots. The obtained results could be summarized as follows:

1- Water saving reached to 20 and $40 \%$ under irrigation onion crop at 80 and $60 \%$ ETo regimes, comparable with $100 \%$ ETo regime. Total onion yield and both Bulb diameter and Single bulb weight were significantly affected due to the adopted treatments in $1^{\text {st }}$ and $2^{\text {nd }}$ seasons. Under100\% ETo regime, higher values of total onion yield, Bulb diameter and Single bulb weight were recorded, comparable with those under 80 and 60\% ETo regimes in $1^{\text {st }}$ and $2^{\text {nd }}$ seasons. Higher values of total onion yield, Bulb diameter and Single bulb weight were observed with $P S_{500}$ foliar application, comparing with those under $P S_{250}, S_{250}$ andSA $A_{500}$. Interaction of $100 \%$ ETo regime and $P S_{500}$ foliar application resulted in higher figures of total onion yield, Bulb diameter and Single bulb weight

2- Total Soluble Solids (TSS), marketable bulb yield\% and dry matter \% were significantly increased under $60 \%$ ETo, whereas the assessed foliar application e.g. PS or SA treatments did not significantly increase such parameters. nteraction of $60 \%$ ETo regime and $S A_{250}$ exhibited higher TSS \%, Dry matter content\% and marketable bulb yield\%\%

3- Values of IWUE tended to increase with reducing irrigation rate and vice versa. Additionally, foliar application of Potassium Silicate at $500 \mathrm{mgL}^{-1}$ concentration ( $P S_{500}$ ) exhibited higher IWUE figures, comparing with $P S_{250}, S A_{250}$ and $S A_{500}$. The $60 \%$ ETo irrigation regime as interacted with foliar application of Potassium Silicate at $500 \mathrm{mgL}^{-1}\left(P S_{500}\right)$ exhibited higher IWUE figures.

4- Under the present experiments circumstances, it is advisable to irrigate the onion crop at100\% ETo regime combined with foliar application of potassium silicate at $500 \mathrm{mgL}^{-1}$ concentration. However, in water constraint situation irrigating at 80 or $60 \%$ ETo regimes and foliar application of potassium silicate at $500 \mathrm{mgL}^{-1}$ concentration is recommended due to irrigation water saving(20 to $40 \%)$ and acceptable onion bulb yield with higher quality and efficient water use as well.

Key words: Deficit irrigation, Onion yield and quality, Potassium Silicate (PS) and Salicylic $\operatorname{Acid}(S A)$, IWUE

\section{INTRODUCTION}

Onions is the most commercially valuable vegetables in Egypt as an export crop. The total cultivated area of onion was about 
115295 fed during 2009 which produced 1563360 tons with average productivity of 13.56 tons/fed (Agricultural Economic Bulletin, Ministry of Agriculture, April 2010). Onion is a shallow-rooted crop that requires frequent irrigation to achieve the yield potential. Cheruth et al. (2008) stated that, plant growth and productivity is adversely affected by various biotic and abiotic stress factors, and water deficit is one of the major abiotic stresses, which adversely affects crop growth and yield. Additionally, water stress reduces plant growth by affecting various physiological and biochemical processes, such as photosynthesis, respiration, translocation, ion uptake, carbohydrates, nutrient metabolism and growth promoters (Jaleel et al., 2008 and Farooq et al., 2008). Al-Moshileh (2007) and Metwally (2011) reported that with increasing soil water supply significant increases were recorded in plant growth parameters, i.e. plant height, number of green leaves and bulb diameter. Bekele and Tilahun (2007) reported that subjecting onion crop to 25,50 , and $75 \%$ ETc water deficit regimes resulted in higher water use efficiency, compared with optimal irrigation. Ayasand Demirtaş (2009), applied to onion crop different amounts of water equals to $100,75,50,25$ and $0 \%$ (as control) of evaporation from a Class A Pan corresponding to 2-day irrigation frequency. Irrigation water applied to the crop varied from 65 to $362 \mathrm{~mm}$, and water consumption ranged from 95 to $372 \mathrm{~mm}$. The effect of irrigation water level on the yield, bulb height, bulb diameter, bulb weight and dry matter ratio were found to be significant.

Nagaz et al. (2012) stated that no significant differences were observed in bulbs fresh and dry yields, bulbs numberha ${ }^{-1}$ and weight from the comparison between full irrigation (100\% ETc) and 80 and $60 \%$ ETc deficit regimes. The authors added that Water use efficiency was the highest for 60\%ETc regime. Gebremedhin (2015) reported that drip irrigation at $100 \%$ ETc gave significantly higher onion yield $(28.0 \mathrm{t}$ ha-1), as compared to 80 and $60 \%$ ETc and irrigation water use efficiency was found highest $(7.60 \mathrm{~kg} \mathrm{~m}-3)$ with drip irrigation at $60 \%$ ETc. Bhagyawant et al. (2015) found that he relative yield decreases of the onion crop were proportionally greater with increase in evapotranspiration deficit, which shows the response of yield with respect to the decrease in water consumption.

Growth substances are used to regulate growth and improve productivity and quality of various plant species. Salicylic acid (SA), a natural signal molecule, has been shown to play an important role in regulating a number of physiological processes in plants. Its exogenous application has promoted plant performance under biotic and abiotic stresses (Senaratna et al. 2000). Exogenous application of salicylic acid may influence stomata closure (Larque, Saaverda1979) and transpiration and stress tolerance (Waseem et. al. 2006). In this respect, Amin et al. (2007) found that foliar application of SA caused significant increase in most growth characters, photosynthetic pigments content/leaves, yield and its quality, total soluble sugars, total free amino acids, total phenols and total indoles of onion plants. It is now clear that SA provides protection against a number of abiotic stresses such as drought stress in wheat plants (Bezrukova et al. 2001). El-Hedek (2013) reported that foliar application of Salicylic acid and potassium silicate increased wheat yield components, and a remarkable increase in potassium, calcium, and phosphorus (\%) of grains and straw was noticed. Yavas and Unay (2016) stated that foliar application of salicylic acid regulated physiological processes in plants and alleviated the adverse effects of water stress.

Potassium silicate is a source of highly soluble potassium and silicon (Si). Silicon is not considered an essential element for plant growth. In many cases, increasing $\mathrm{Si}$ availability has increased crop development and yield, once this nutrients can indirectly influence some photosynthetic and 
biochemical aspects, especially in plants under biotic or abiotic stress conditions (Ma and Yamaji, 2006).Further studies indicated that silicate application significantly increased plant growth under normal and stress condition including both biotic and abiotic stresses (Hattori et al.,2008 and Tahir et al. 2010;). A number of possible mechanisms through which silicate may increase salinity tolerance in plants including improved plant water status (RomeroArnada et al. 2006).

The objectives of this work were to study: (i) The effect of irrigation (full and deficit regimes) on the yield and quality characteristics of onion, (ii) The role of foliar application of salicylic acid and potassium silicates in enhancing onion yield and quality under deficit irrigation condition, and (iii) The interaction effect of the adopted irrigation regimes and foliar application of salicylic acid and potassium silicates on the yield and quality characteristics of onion.

\section{MATERIALS AND METHODS The experimental site:}

A field experiment was conducted at ElBostan area at AlyMubark experimental farm, south Tahrirregion during 2011/2012 and 2012/2013winter seasons to study the effect of irrigation regime and the foliar application of Potassium Silicate (PS) and Salicylic Acid (SA)and their interaction on onion yield and quality and irrigation water use efficiency under drip irrigation. Soil physical and chemical properties at the experimental site were determined according to klute (1986) and Page et al. (1982), and presented in Tables (1 and 2).

\section{THE experimental treatments}

The treatments were irrigation with amounts of water equal to 100,80 and $60 \% \mathrm{ET}_{0}$, based on evaporation data of class A pan evaporation located in South El-Tahrir metrological station, and foliar application of Potassium Silicate (PS) and Salicylic Acid (SA) at 250 and $500 \mathrm{mgL}^{-1}$ rates for both. Seed bed preparation, mineral and organic fertilizers and other agricultural practices were done as recommended by Field Crop Research Institute, Agriculture Research Center. The adopted treatments were assessed in a spilt plot design with four replicates. The main plots were assigned to the irrigation treatments, while the sub plots were assigned to foliar application of PS and SA. The experimental unit consists of six drip irrigation lines (Jensen 1983). Onion seedlings (Allium cape, L. variety Giza 20) was transplanted on the $10^{\text {th }}$ December and the yield was harvested on $30^{\text {th }}$ May of both seasons. A total $45 \mathrm{~mm}$ of irrigation water was daily applied in ten portions to ensure good plant establishment.

Table 1. Some soil- water properties and particle size distribution of the experimental site

\begin{tabular}{|c|c|c|c|c|c|c|c|c|}
\hline \multirow{2}{*}{$\begin{array}{l}\text { Soil } \\
\text { depth } \\
(\mathrm{cm})\end{array}$} & \multirow{2}{*}{$\begin{array}{c}\text { F.C. }^{*} \\
(\%, w / w)\end{array}$} & \multirow{2}{*}{$\begin{array}{l}\text { W.P.* } \\
(\%, w / w)\end{array}$} & \multirow{2}{*}{$\begin{array}{l}\text { A.W.' } \\
(\%, w / w)\end{array}$} & \multirow{2}{*}{$\begin{array}{c}\mathrm{BD}^{*} \\
\left(\mathrm{gcm}^{-3}\right)\end{array}$} & \multicolumn{3}{|c|}{$\begin{array}{c}\text { Particle size } \\
\text { distribution, \% }\end{array}$} & \multirow{2}{*}{$\begin{array}{c}\text { Texture } \\
\text { class }\end{array}$} \\
\hline & & & & & Sand & Silt & Clay & \\
\hline $00-15$ & 12.1 & 5.4 & 6.7 & 1.45 & 92.9 & 2.7 & 4.4 & Sandy \\
\hline $15-30$ & 11.9 & 5.1 & 6.8 & 1.60 & 91.3 & 4.6 & 4.1 & Sandy \\
\hline $30-45$ & 10.4 & 4.2 & 6.2 & 1.72 & 90.5 & 5.6 & 3.9 & sandy \\
\hline
\end{tabular}

${ }^{*}$ F.C. is field capacity, W.P. is wilting point, A.W. is available water, and BD is soil bulk density.

Table (2): Some soil chemical properties of experimental site

\begin{tabular}{|c|c|c|c|c|c|c|c|c|c|}
\hline $\begin{array}{c}\text { Soil depth } \\
(\mathrm{cm})\end{array}$ & $\begin{array}{c}\mathrm{EC} \\
\left.(\mathrm{dScm})^{1}\right)\end{array}$ & $\mathrm{pH}$ & $\mathrm{Ca}^{+2}$ & $\mathrm{Mg}^{+2}$ & $\mathrm{Na}^{+}$ & $\mathrm{K}^{+}$ & $\mathrm{HCO}_{3}{ }^{-}$ & $\mathrm{SO}_{4}{ }^{-2}$ & $\mathrm{Cl}^{-}$ \\
\hline $00-30$ & 0.45 & 8.6 & 1.20 & 0.65 & 1.60 & 0.20 & 1.17 & 0.64 & 1.84 \\
\hline $30-60$ & 0.38 & 8.8 & 1.15 & 0.50 & 1.40 & 0.20 & 1.03 & 0.52 & 1.7 \\
\hline
\end{tabular}




\section{Crop-water relationships:}

i. Reference Evapotranspiration $\left(E T_{0}\right)$ :

The $\mathrm{ET}_{0}$ was calculated using the class $\mathrm{A}$ pan evaporation method (Doorenbos and Kassam, 1986) by using the following equation:

Where:

$$
\text { ETo }=\text { Epan } \times \text { Kpan }
$$

$E T_{0}$ : reference evapotranspiration $\left(\mathrm{mm} \mathrm{d}^{-1}\right)$ $E_{p a n}$ : daily measured pan evaporation ( $\mathrm{mm}$ $\mathrm{d}^{-1}$ )

$K_{\text {pan }}$ : A value of 0.75 was used for the experimental site according to the climatic local condition (FAO, 1970).

\section{ii. Applied Irrigation Water (AIW):}

The mount of applied irrigation water was calculated according to the following equation as described by Vermeirer and Topling (1984).

Where:

$$
A I W=(E T o x \mathrm{Kr} \times \mathrm{I} / \mathrm{Ea})+\mathrm{LR}
$$

AIW: depth of applied irrigation water $(\mathrm{mm})$ $\mathrm{ET}_{0}$ : reference evapotranspiration $\left(\mathrm{mmd}^{-1}\right)$

$\mathrm{Kr}$ : evaporation reduction coefficient, depend on ground cover, a value of 1.0 was used (where the spacing between drip lines is less than $1.8 \mathrm{~m}, \mathrm{FAO}, 56$ ),

$\mathrm{I}$ : irrigation intervals (days),

$E_{a}$ : irrigation efficiency of the drip irrigation system, an average value of 0.8 was used.

LR: leaching requirements $(10 \%$ of the calculated applied irrigation water was additionally applied per irrigation during the growing season for leaching purposes)

Irrigation time was determined before each irrigation event by measuring the actual emitter discharge according to the equation given by Ismail, (2002) as follows:

Where:

$$
t=(A I W x A) / q
$$

AIW: applied irrigation water

$\mathrm{t}$ : irrigation time $(\mathrm{h})$,

A : wetted area $\left(\mathrm{m}^{2}\right)$,

q: emitter discharge $\left(\mathrm{Lh}^{-1}\right)$.

\section{iii. Irrigation Water Use Efficiency (IWUE):}

Irrigation Water Use Efficiency (IWUE) was calculated according to Gebremedhin (2015) as follows:

IWUE $=$ Onion yield $\left(\mathrm{kgfed}^{-1}\right) /$ Applied irrigation water $\left(\mathrm{m}^{3} \mathrm{fed}{ }^{-1}\right)$

\section{Measured crop parameters:}

Onion plants were harvested at 30 May, in $1^{\text {st }}$ and $2^{\text {nd }}$ seasons, and leftfor one week in the field. The studied parameters were: onion bulbs yield, bulb diameter and average weight of individual bulbs, marketable bulb yield\%, total soluble solids (TSS\%)and dry matter percent\%.

\section{Statistical analysis:}

The obtained data were statistically analyzed using statistical package (CoHort, 1986). The mean values for the four replicates of each treatment were interpreted using the analysis of variance (ANOVA). The Duncan's Multiple Range Test was used for comparisons between different sources of variance according to Steel and Torrie (1984).

\section{RESULTS AND DISCUSSION 1. Applied irrigation water:}

The amounts of applied irrigation water based on reference evapotranspiration $\left(E T_{0}\right)$, which calculated based on $E_{p a n}$ records are presented in Table (3). Higher values of applied irrigation water e.g.132.10 and $101.17 \mathrm{~mm}$ were noticed in April and May, respectively. A total amount of $45 \mathrm{~mm}$ of irrigation water was daily applied in ten portions to ensure good plant establishment, thus the total applied irrigation water for were $512.68,410.14$, and $307.61 \mathrm{~mm}$ for 100 , 80 and $60 \%$ ETo irrigation regimes, respectively. On such basis, water saving due to irrigation according to 80 or $60 \%$ ETo regimes are 20.0 and $40.0 \%$, respectively, comparable with $100 \%$ ETo regime. In this respect, Kumar et al. (2007b) with micro sprinkler - irrigated onion based on IW/ CPE 
ratio e.g. $0.60,0.80,1.0$ and 1.20 , reported that water saving under 0.60 ranged $(24.95$ $-18.28 \%),(36.84-33.84 \%)$ and $(44.99-$ $42.92 \%)$ comparing with $0.80,1.0$ and 1.20 IW/ CPE ratios, respectively. In addition, Nagaz et al. (2012) in 2 - season experiment on drip - irrigated onion, reported that water saving with 80 or $60 \%$ ETc regimes ranged $432-426 \mathrm{~mm}$ and 333 - $332 \mathrm{~mm}$, respectively, comparing with 530 $-521 \mathrm{~mm}$ under $100 \%$ ETc regime.

\section{Yield and yield components:}

Data in Table 4 indicated that total onion yield and both Bulb diameter and Single bulb weight were significantly affected due to the adopted treatments in $1^{\text {st }}$ and $2^{\text {nd }}$ seasons. Under $100 \%$ ETo regime, total onion yield increased by (18.05 and $18.08 \%$ ) and by $(57.43$ and $54.97 \%)$ more than those under 80 and $60 \%$ ETo regimes, respectively, in $1^{\text {st }}$ and $2^{\text {nd }}$ seasons. The obtained results are in parallel with those reported by Sammis et al. (2000), AlMoshileh (2007), and Mermoud et al. (2005) who indicated that decreasing amount of applied irrigation water resulted in decreasing total onion yield. In addition,
Gebremedhin (2015) irrigating onion crop at $100 \%$ ETc regime gave significantly higher onion yield (28.0 t ha $\left.{ }^{-1}\right)$, as compared to 80 and $60 \%$ ETc regimes. Furthermore, Bhagyawant (2015) reported that the relative yield decreases of the onion crop were proportionally greater with increase in evapotranspiration deficit.

Similarly, Bulb diameter and Single bulb weight exhibited the same trend, where higher values were recorded with $100 \%$ ETo regime. The increase in Bulb diameter under $100 \%$ ETo regime amounted to 18.08 and $46.76 \%$ in $1^{\text {st }}$ and to 8.64 and $34.51 \%$ in $2^{\text {nd }}$ season respectively, comparable to 80 and $60 \%$ ETo regimes. In addition, the increase in Single bulb weight under $100 \%$ ETo regime reached to 12.51 and $126.73 \% \%$ in $1^{\text {st }}$ season and to 11.77 and $42.84 \%$ in $2^{\text {nd }}$ season, respectively, comparing with 80 and $60 \%$ ETo regimes. The present results are agreed with those of El-Haris and Abdel Razek (1997) and Metwaly (2011), who reported that onion yield components generally improved with increasing total water applied during the growing period.

Table (3): Average reference evapotranspiration ( $\mathrm{ET}_{0}$ ) values and the amount of applied irrigation for the two growing seasons

\begin{tabular}{|l|c|c|c|}
\hline Month & $\begin{array}{c}\text { Growth period } \\
\text { (Day) }\end{array}$ & $\begin{array}{c}\text { Reference } \\
\text { evapotranspiration } \\
\left(\mathrm{ET}_{0}\right)\end{array}$ & $\begin{array}{c}\text { Applied irrigation water } \\
(\mathrm{mm})\end{array}$ \\
\hline December & 21 & 21.83 & 30.01 \\
\hline January & 31 & 35.55 & 48.88 \\
\hline February & 29 & 43.80 & 60.23 \\
\hline March & 31 & 69.30 & 95.29 \\
\hline April & 30 & 96.08 & 132.10 \\
\hline May & 20 & 73.85 & 101.17 \\
\hline Total & 162 & 340.41 & 467.68 \\
\hline
\end{tabular}


Abd El-All, et al.,

Table (4): Effect of irrigation regimes and foliar application of potassium silicates (PS) and Salicylic acid (SA) on onion yield, bulb diameter and single bulb weight

\begin{tabular}{|c|c|c|c|c|c|c|c|c|c|c|}
\hline \multicolumn{11}{|c|}{ Total yield ( ton/fed) } \\
\hline \multirow[b]{2}{*}{ Treat. } & \multicolumn{5}{|c|}{ 2011/2012 } & \multicolumn{5}{|c|}{ 2012/2013 } \\
\hline & $\begin{array}{c}100 \% \\
\text { ETo }\end{array}$ & $\begin{array}{l}80 \% \\
\text { ETo }\end{array}$ & $\begin{array}{l}60 \% \\
\text { ETo }\end{array}$ & Mean & $\begin{array}{l}\text { LSD } \\
0.05\end{array}$ & $\begin{array}{c}100 \% \\
\text { ETo }\end{array}$ & $\begin{array}{l}80 \% \\
\text { ETo }\end{array}$ & $\begin{array}{l}60 \% \\
\text { ETo }\end{array}$ & Mean & $\begin{array}{l}\text { LSD } \\
0.05\end{array}$ \\
\hline $\mathrm{PS}_{250}$ & 17.81 & 15.03 & 11.25 & 14.70 & \multirow{4}{*}{0.21} & 17.11 & 14.64 & 10.84 & 14.20 & \multirow{4}{*}{0.47} \\
\hline $\mathrm{PS}_{500}$ & 18.30 & 16.29 & 12.57 & 15.72 & & 17.88 & 15.88 & 12.16 & 15.31 & \\
\hline $\mathrm{SA}_{250}$ & 17.60 & 14.21 & 10.53 & 14.11 & & 17.18 & 13.76 & 10.12 & 13.70 & \\
\hline $\mathrm{SA}_{500}$ & 17.48 & 14.71 & 10.86 & 14.35 & & 17.05 & 14.30 & 11.55 & 14.30 & \\
\hline Mean & 17.79 & 15.07 & 11.30 & & & 17.31 & 14.66 & 11.17 & 14.20 & \\
\hline LSD0.05 & \multicolumn{3}{|c|}{1.11} & & & \multicolumn{3}{|c|}{1.05} & & \\
\hline \multicolumn{11}{|c|}{ Bulb diameter $(\mathrm{cm})$} \\
\hline $\mathrm{PS}_{250}$ & 7.26 & 6.12 & 4.92 & 6.10 & \multirow{4}{*}{0.12} & 6.80 & 6.50 & 5.22 & 6.17 & \multirow{4}{*}{0.14} \\
\hline $\mathrm{PS}_{500}$ & 7.46 & 6.64 & 5.46 & 6.52 & & 7.05 & 6.59 & 5.37 & 6.33 & \\
\hline $\mathrm{SA}_{250}$ & 7.17 & 5.78 & 4.62 & 5.86 & & 6.83 & 6.27 & 4.98 & 6.02 & \\
\hline $\mathrm{SA}_{500}$ & 7.12 & 5.99 & 4.76 & 5.96 & & 6.79 & 5.92 & 4.83 & 5.84 & \\
\hline Mean & 7.25 & 6.14 & 4.94 & & & 6.86 & 6.32 & 5.10 & & \\
\hline LSD0.05 & \multicolumn{3}{|c|}{0.39} & & & \multicolumn{3}{|c|}{0.42} & & \\
\hline \multicolumn{11}{|c|}{ Single bulb weight (g) } \\
\hline $\mathrm{PS}_{250}$ & 102.12 & 90.66 & 74.69 & 89.15 & \multirow{4}{*}{1.87} & 104.29 & 94.67 & 73.09 & 90.68 & \multirow{4}{*}{0.74} \\
\hline $\mathrm{PS}_{500}$ & 104.14 & 95.82 & 80.33 & 93.43 & & 105.90 & 96.93 & 73.45 & 92.09 & \\
\hline $\mathrm{SA}_{250}$ & 101.24 & 87.12 & 71.83 & 86.73 & & 104.42 & 90.95 & 66.78 & 87.38 & \\
\hline$S A_{500}$ & 100.71 & 89.23 & 73.19 & 87.71 & & 102.98 & 91.07 & 66.82 & 86.96 & \\
\hline Mean & 102.05 & 90.70 & 75.00 & & & 104.40 & 93.41 & 73.09 & & \\
\hline LSD0.05 & & 4.61 & & & & & 5.96 & & & \\
\hline
\end{tabular}

Data in Table 4 indicated higher total onion yield with $\mathrm{PS}_{500}$ foliar application, which surpassed those under $\mathrm{PS}_{250}, \mathrm{SA}_{250}$ and $\mathrm{SA}_{500}$ by $6.94,11.40$ and $9.55 \%$ in $1^{\text {st }}$ season, and by $7.82,11.75$ and $7.82 \%$ in $2^{\text {nd }}$ season, respectively. In this sense, Amin et al. (2007) reported that onion yield gradually responded positively with increasing $\mathrm{SA}$ concentration up to $200 \mathrm{mgL}^{-1}$. Bulb diameter and Single bulb weight exhibited similar trends, where Bulb diameter was increased with $\mathrm{PS}_{500}$ foliar application by
$6.88,11.26$ and $9.40 \%$ in $1^{\text {st }}$ season, and by $2.59,4.90$ and $8.39 \%$ in $2^{\text {nd }}$ season, respectively, comparable with $\mathrm{PS}_{250}, \mathrm{SA}_{250}$ and $S_{500}$. The increases in Single bulb weight under $\mathrm{PS}_{500}$ foliar application comprised $4.80,7.73$ and $6.52 \%$ in $1^{\text {st }}$ season, and by $1.55,5.39$ and $5.90 \%$ in $2^{\text {nd }}$ season, respectively, in the same order of treatments. Interaction of $100 \%$ ETo regime and $\mathrm{PS}_{500}$ foliar application resulted in higher figures of total onion yield, Bulb diameter and Single bulb weight in $1^{\text {st }}$ and $2^{\text {nd }}$ 
seasons. Such findings are attributable to improving onion performance due to foliar application of Potassium Silicate, Ma and Yamaji (2006).

\section{Total soluble solids, single center bulb, and dry matter contents}

Data in Table 5 showed that Total Soluble Solids (TSS), Marketable bulb yield $\%$ and Dry matter content $\%$ were significantly influenced due to the adopted irrigation regimes, whereas the assessed foliar application e.g. Potassium Silicate or Salicylic Acid treatments did not significantly affect such parameters, and that trend was true in $1^{\text {st }}$ and $2^{\text {nd }}$ seasons. Irrigating onion crop at $60 \%$ ETo regime resulted in higher values of TSS $\%$, marketable bulb yield\% and dry matter content $\%$, in $1^{\text {st }}$ and $2^{\text {nd }}$ seasons. The TSS\% values were increased by 37.28 and $20.12 \%$ in $1^{\text {st }}$ season, and by 35.44 and $15.72 \%$ in $2^{\text {nd }}$ season, respectively, comparable with 100 and $80 \%$ ETo regimes. The corresponding increases in marketable bulb yield\% amounted to (18.86 and 10.46\%) and (19.53 and 8.83\% $\%)$, respectively, in $1^{\text {st }}$ and $2^{\text {nd }}$. As for dry matter content\%, the increases reached to (21.59 and $11.34 \%$ ) and (56.44 and $3.40 \%$ $\%$, respectively, in the same order of treatments and seasons. In connection, Metwaly (2011) reported that dry matter content showed highly negative correlation with applied water.

Table (5): Effect of irrigation regimes and foliar application of potassium silicate and Salicylic acid on total soluble solids, marketable bulb yield and dry matter\%

\begin{tabular}{|c|c|c|c|c|c|c|c|c|c|c|}
\hline \multicolumn{6}{|c|}{ 2011/2012 } & \multicolumn{5}{|c|}{ 2012/2013 } \\
\hline \multirow[b]{2}{*}{ Treatment $^{* *}$} & \multicolumn{10}{|c|}{ Total soluble solids (TSS \%) } \\
\hline & $\begin{array}{c}100 \% \\
\text { ETo }\end{array}$ & $\begin{array}{l}80 \% \\
\text { ETo }\end{array}$ & $\begin{array}{l}60 \% \\
\text { ETo }\end{array}$ & Mean & $\begin{array}{c}\text { LDS } \\
(0.05)\end{array}$ & $\begin{array}{c}100 \% \\
\text { ETo }\end{array}$ & $\begin{array}{l}80 \% \\
\text { ETo }\end{array}$ & $\begin{array}{l}60 \% \\
\text { ETo }\end{array}$ & Mean & $\begin{array}{c}\text { LDS } \\
(0.05)\end{array}$ \\
\hline $\mathrm{PS}_{250}$ & 10.56 & 12.08 & 14.53 & 12.39 & \multirow{4}{*}{ N.S. ${ }^{*}$} & 11.08 & 12.99 & 15.08 & 13.08 & \multirow{4}{*}{ N.S. } \\
\hline $\mathrm{PS}_{500}$ & 10.43 & 11.75 & 14.17 & 12.11 & & 10.92 & 12.58 & 14.58 & 12.70 & \\
\hline $\mathrm{SA}_{250}$ & 10.61 & 12.30 & 14.69 & 12.54 & & 11.15 & 13.27 & 15.26 & 13.22 & \\
\hline $\mathrm{SA}_{500}$ & 10.67 & 12.17 & 14.63 & 12.49 & & 11.20 & 13.10 & 15.15 & 13.15 & \\
\hline Mean & 10.57 & 12.08 & 14.51 & & & 11.09 & 12.98 & 15.02 & & \\
\hline LSD0.05 & \multicolumn{3}{|c|}{1.57} & & & \multicolumn{3}{|c|}{1.74} & & \\
\hline \multicolumn{11}{|c|}{ Marketable bulb yield, \% } \\
\hline $\mathrm{PS}_{250}$ & 68.96 & 74.47 & 82.08 & 75.17 & \multirow{4}{*}{ N.S. } & 68.63 & 74.61 & 83.11 & 75.45 & \multirow{4}{*}{ N.S. } \\
\hline $\mathrm{PS}_{500}$ & 67.98 & 71.99 & 79.43 & 73.13 & & 69.33 & 74.77 & 82.11 & 75.41 & \\
\hline $\mathrm{SA}_{250}$ & 69.38 & 76.16 & 83.51 & 76.35 & & 70.26 & 79.11 & 84.63 & 78.00 & \\
\hline $\mathrm{SA}_{500}$ & 69.64 & 75.15 & 82.86 & 75.88 & & 71.44 & 78.65 & 84.39 & 78.16 & \\
\hline Mean & 68.98 & 74.44 & 81.97 & & & 69.91 & 76.78 & 83.56 & & \\
\hline LSD0.05 & \multicolumn{3}{|c|}{2.21} & & & \multicolumn{3}{|c|}{2.31} & & \\
\hline \multicolumn{11}{|c|}{ Dry matter content, \% } \\
\hline $\mathrm{PS}_{250}$ & 13.57 & 14.81 & 16.52 & 14.97 & \multirow{4}{*}{ N.S. } & 14.52 & 15.63 & 16.20 & 15.45 & \multirow{4}{*}{ N.S. } \\
\hline $\mathrm{PS}_{500}$ & 13.35 & 14.29 & 15.92 & 14.53 & & 14.25 & 15.02 & 15.55 & 14.94 & \\
\hline $\mathrm{SA}_{250}$ & 13.66 & 15.19 & 16.85 & 15.24 & & 14.53 & 15.91 & 16.44 & 15.62 & \\
\hline $\mathrm{SA}_{500}$ & 13.68 & 14.96 & 16.70 & 15.15 & & 14.71 & 15.81 & 16.30 & 15.60 & \\
\hline Mean & 13.57 & 14.82 & 16.50 & & & 14.05 & 15.59 & 16.12 & & \\
\hline LSD0.05 & \multicolumn{3}{|c|}{1.12} & & & \multicolumn{3}{|c|}{1.09} & & \\
\hline
\end{tabular}

${ }^{*} N$.S. is not significant at $5 \%$ probability level.

** PS $250 ; P S_{500} ; S A_{250}$ and $S A_{500}$ are referred to Potassium Silicate $\left(250 \mathrm{mgL}^{-1}\right)$, Potassium Silicate (500 $\left.\mathrm{mgL}^{-1}\right)$, Salicylic Acid $\left(250 \mathrm{mgL}^{-1}\right)$ and Salicylic Acid $\left(500 \mathrm{mgL}^{-1}\right)$, respectively. 
As mentioned above, that foliar application neither Potassium Silicate nor Salicylic Acid treatments significantly altered Total Soluble Solids (TSS), Single center bulb and Dry matter content\%. However, $\mathrm{SA}_{250}$ exhibited higher values of TSS and Dry matter content\%. The increases in TSS $\%$ with $S_{250}$ were $1.21,3.55$ and $0.40 \%$ under $\mathrm{PS}_{250}, \mathrm{PS}_{500}$ and $\mathrm{SA}_{500}$, respectively, in $1^{\text {st }}$ season. The corresponding increases in $2^{\text {nd }}$ were $1.07,4.09$ and $0.53 \%$, respectively, in the same order of the treatments. Additionally, the increases in Dry matter content\% due to $\mathrm{SA}_{250}$ amounted to $1.81,4.89$ and $0.59 \%$ in $1^{\text {st }}$ season, and by $1.10,4.55$ and $0.13 \%$ in $2^{\text {nd }}$ season, respectively, comparing with $\mathrm{PS}_{250}, \mathrm{PS}_{500}$ and $S_{500}$. With respect to Single center bulb\%, the trend was slightly different, where higher values were noticed with $\mathrm{SA}_{250}$ in $1^{\text {st }}$ season and with $\mathrm{SA}_{500}$ in $2^{\text {nd }}$ season. Amin et al. (2007) found that sugar content\% and dry weight\% of onion bulb were increased with SA concentration up to $100 \mathrm{mgL}^{-1}$, and tended to reduce with 200 $\mathrm{mgL}^{-1}$ one. Interaction of $60 \%$ ETo regime and $\mathrm{SA}_{250}$ exhibited higher TSS \%, Dry matter content\% and Single center bulb\% in $1^{\text {st }}$ and $2^{\text {nd }}$ seasons.

\section{Irrigation Water Use Efficiency (IWUE):}

Results in Table (6) showed that IWUE tended to increase with reducing irrigation rate and vice versa, and that trend was true in $1^{\text {st }}$ and $2^{\text {nd }}$ seasons. The increases were 5.68 and $5.80 \%$ in $1^{\text {st }}$ season, and 5.72 and $7.46 \%$ in $2^{\text {nd }}$ season, respectively, under 80 and $60 \%$ ETo regimes, comparable with $100 \%$ regime. Ayas et al. (2009) found that the highest values of irrigation water use efficiency (IWUE) of onion was $12.71 \mathrm{~kg}$ $\mathrm{mm}^{-1}$ for the 0.50 Pan co efficient treatment, comparing with $1.00,0.75$ and 0.25 ones. Kumar et al. (2007b) with micro sprinkler irrigated onion based IW/ CPE ratio of 0.60 , $0.80,1.0$ and 1.20, and found Irrigation water use efficiency was highest in 0.8 and then declined with the increase in irrigation. Additionally, the present findings are in accordance with those reported by Gebremedhin (2015) who stated that irrigation water use efficiency for drip irrigated onion, was the highest $\left(7.60 \mathrm{kgm}^{-3}\right)$ with $60 \%$ ETc, compared with 100 and $80 \%$ crop ET irrigation regimes.

Table (6): Effect of irrigation regimes and foliar application of potassium silicate and Salicylic acid on Irrigation Water Use Efficiency (IWUE) in 2012 and 2013

\begin{tabular}{|c|c|c|c|c|c|c|c|c|}
\hline \multirow{3}{*}{ Treatments* } & \multicolumn{8}{|c|}{ IWUE, $\mathbf{k g m}^{-3}$} \\
\hline & \multicolumn{4}{|c|}{ 2011/2012 } & \multicolumn{4}{|c|}{ 2012/2013 } \\
\hline & $\begin{array}{c}100 \% \\
\text { ETo }\end{array}$ & $\begin{array}{l}80 \% \\
\text { ETo }\end{array}$ & $\begin{array}{l}60 \% \\
\text { ETo }\end{array}$ & Mean & $\begin{array}{c}100 \% \\
\text { ETo }\end{array}$ & $\begin{array}{l}80 \% \\
\text { ETo }\end{array}$ & $\begin{array}{l}60 \% \\
\text { ETo }\end{array}$ & Mean \\
\hline $\mathrm{PS}_{250}$ & 8.27 & 8.73 & 8.71 & 8.57 & 7.95 & 8.50 & 8.39 & 8.28 \\
\hline $\mathrm{PS}_{500}$ & 8.50 & 9.46 & 9.73 & 9.23 & 8.30 & 9.22 & 9.41 & 8.98 \\
\hline $\mathrm{SA}_{250}$ & 8.17 & 8.25 & 8.15 & 8.19 & 7.98 & 7.99 & 7.83 & 7.93 \\
\hline $\mathrm{SA}_{500}$ & 8.12 & 8.54 & 8.41 & 8.35 & 7.92 & 8.30 & 8.94 & 8.39 \\
\hline Mean & 8.27 & 8.74 & 8.75 & 8.59 & 8.04 & 8.50 & 8.64 & 8.39 \\
\hline
\end{tabular}

${ }^{*} P S_{250} ; P S_{500} ; S A_{250}$ and $S A_{500}$ are referred to Potassium Silicate $\left(250 \mathrm{mgL}^{-1}\right)$, Potassium Silicate $(500$ $\left.\mathrm{mgL}^{-1}\right)$, Salicylic Acid $\left(250 \mathrm{mgL}^{-1}\right)$ and Salicylic Acid $\left(500 \mathrm{mgL}^{-1}\right)$, respectively. 
Foliar application of Potassium Silicate at 500 ppm (PS $\left.{ }_{500}\right)$ exhibited higher IWUE figures, where the increases under $\mathrm{PS}_{500}$ comprised $7.54, \quad 12.70$ and $10.54 \%$ respectively, comparing with $\mathrm{PS}_{250}, \mathrm{SA}_{250}$ and $\mathrm{SA}_{500}$ in $1^{\text {st }}$ season. The corresponding increases in $2^{\text {nd }}$ season were $8.45,13.24$ and $7.03 \%$ in the same order of the treatments. The $60 \%$ ETo irrigation regime as interacted with foliar application of Potassium Silicate at $500 \mathrm{mgL}^{-1}\left(\mathrm{PS}_{500}\right)$ exhibited higher IWUE figures e.g. 9.73 and $9.41 \mathrm{kgm}^{-3}$ in $1^{\text {st }}$ and $2^{\text {nd }}$ seasons, respectively.

\section{CONCLUSION:}

On conclusion, under the experiment situations and in order to attain the potentiality of onion bulb yield it is advisable to irrigate the onion cropat $100 \%$ ETo regime combined with foliar application of potassium silicate at $500 \mathrm{mgL}^{-1}$ concentration. However, in water constraint situation irrigating at 80 or $60 \%$ ETo regimes and foliar application of potassium silicate at $500 \mathrm{mgL}^{-1}$ concentration is recommended due to irrigation water saving (20 to $40 \%$ ) and obtaining an acceptable onion bulb yield with higher quality and efficient water use as well.

\section{REFERENCES}

Agricultural Economic Bulletin, Ministry of Agriculture, April (2010).

Al-Moshileh, A.M, (2007). Effects of Planting Date and Irrigation Water Level on Onion (Allium cepa L.) Production under Central Saudi Arabian conditions. Sci. J. King Faisal University (Basic and Applied Sciences), 8(1): 1428.

Amin A. A., EL-Sh. M. Rashad and H.M.H. EL-Abagy (2007). Physiological Effect of Indole - 3 - Butyric Acid and Salicylic Acid on Growth, Yield and Chemical Constituents of Onion Plants. J. of Appl. Sci. Res., 3(11): 1554-1563.

Ayas, Serhat and Ç. Demirtaş (2009). Deficit irrigation effects on onion (Allium cepa L. E.T. Grano 502) yield in unheated greenhouse condition. Journal of Food, Agriculture \& Environment, Vol.7 (3\&4): $239-243$.
Bekele, S. and K. Tilahun (2007). Regulated deficit irrigation scheduling of onion in a semiarid region of Ethiopia Agric. water manag., 8(9): $148-152$.

Bezrukova, M.V., A.R. Sakhabutdinova, R.A. Fatkhutdinova, I. Kildrirova and R.M. Shakirova (2001). Effect of salicylic acid on root hormone content and the growth of wheat sprouts under water deficit. Agrochemya. 2: 51-54.

Cheruth, A.J., R. Gopi, B. Sankar, M. Gomathinayagam and R. Panneerselvam (2008). Differential responses in water use efficiency in two varieties of Catharanthusroseus under drought stress. Comptesrendus. Biologies. 331(1): 42-47.

CoHort Software. (1986). Costat Statistical package (version 3.03), Berkeley, CA, USA.

Doorenbos, J. and A. Kassam (1986). Yield response to water. FAO, Irrigation \& Drainage paper No. 33, Rome, Italy FAO. (1970). Physical and Chemical Methods of Soil and Water Analysis. Soils Bull. No. 10, FAO, Rome, Italy.

El-Haris, M.K. and R.H. Abdel Razek (1997). Effect of water quantity on onion yield under sprinkler irrigation. Alex. Jour. of Agric. Res., 42(2): 127-135.

El-Hedek, K. S. (2013). Effect of Foliar Applications of Salicylic Acid and Potassium Silicate on Tolerance of Wheat Plants to Soil Salinity. J. Soil Sci. and Agric. Eng., Mansoura Univ., Vol. 4 (3): $335-357$.

FAO. (1970). Physical and Chemical Methods of Soil and Water Analysis. Soils Bull. No. 10, FAO, Rome, Italy.

Farooq, M., S.M.A. Basra, A. Wahid, Z.A. Cheema, M.A. Cheema and A. Khaliq (2008). Physiological role of exogenously applied glycinebetaine in improving drought tolerance of fine grain aromatic rice (Oryza sativa L.). Agron. Crop Sci. 194: 325-333.

Hattori, T., K. Sonobe, S. Inanaga, P.An, and S. Morita (2008). Effects of silicon on photosynthesis of young cucumber 
seedlings under osmotic stress. J. Plant Nutr.31:1046-1058.

Ismail, S.M. (2002). Design and Management of field Irrigation System. (in Arabic), 1st Ed, Monshaet El-Maaref Publication, Alexandria, Egypt.

Jaleel, C.A., R. Gopi, B. Sankar, M. Gomathinayagam and R. Panneerselvam (2008). Differential responses in water use efficiency in two varieties of Catharanthusroseus under drought stress. Comp. Rend. Biol. 331: 42-47.

Jensen, M.E. (1983). Design and Operation of Farm Irrigation Systems. American Society Agricultural Engineering, St. Joseph, USA, Pp. 827.

Klute, A. (1986). Methods of Soil Analysis. Part-1: Physical and Mineralogical Methods ( $2^{\text {nd }}$ ed.) American Society of Agronomy, Madison, Wisconsin. U.S.A.

Kumar, S., M. Imtiyaz and A. Kumar (2007a). Effect of differential soil moisture and nutrient regimes on postharvest attributes of onion (Allium cepa L.). Sci. Hort.112: 121-129.

Kumar, S., M. Imtiyaz, A. Kumar and R. Singh (2007b). Response of onion (Allium cepa L.) to different levels of irrigation water. Agricultural water management, 89:161-166.

Larque, Saaverda A. (1979). Stomatal closure in response to acetyl salicylic acid treatment. Z. Planzeophysiol., 93: 371-375.

Ma. J.F. and N. Yamaji (2006). Silicon uptake and accumulation in higher plants. Trends in Plant Science. 11(8):342-397.

Mermoud, A., T.D. Tamini and H. Yacouba (2005). Impacts of different irrigation schedules on the water balance components of an onion crop in a semiarid zone. Agric. Water Management, 77: 282-295.

Metwally, A.K. (2011). Effect of water supply on vegetative growth and Yield characteristics in onion. Aust.J.Basic\&Appl.Sci., 5(12):3016-3023.
Nagaz, K., M. M. Masmoudi and N. BenMechlia (2012). Yield Response of Drip-Irrigated Onion under Full and Deficit Irrigation with Saline Water in Arid Regions of Tunisia. International Scholarly Research Network, ISRN Agronomy, Vol. 2012: 1 - 8.

Page, A.L., R.H. Miller and D.R. Keeney (eds.) (1982). Methods of Soil Analysis. Part-2: Chemical and Microbiological Properties. ( $2^{\text {nd }}$ ed.) American Society of Agronomy, Madison, Wisconsin. USA.

Romero-Arnada, M.R., O. Jourada and J. Cuartero (2006). Silicon alleviates the deleterious salt effects on tomato plant growth by improving plant water status. J. Plant Physio. 163:847-855

Sammis, T.W., M.S. Al-Jammal, S. Ball and D. Smeal (2000). Crop water use of onion. In: Proceedings of sixth International Micro Irrigation Congress, Micro 2000, Cape Town, South Africa, 19.

Senaratna, T., D. Touchell, E. Bunn and K. Dixon (2000). Acetyl salicylic acid (Aspirin) and salicylic acid induce multiple stress tolerance in bean and tomato plants. Plant Growth Regul. 30: 157-161.

Steel, R.G. and T.H. Torrie (1984). Principals and Procedures of Statistics. McGrow Hill, Now York, USA.

Tahir, M.A., A. Rahmatullah, T. Aziz and M. Ashraf (2010). Wheat genotypes differed significantly in their response to silicon nutrition under salinity stress. J. Plant Nutr. 33:1658-1671.

Vermeirer, L. and G.A. Topling (1984). Localized irrigation FAO. Irrigation paper No.36. Rome, Italy.

Waseem, M., H.U.R. Alhar and M. Ashraf (2006). Effect of salicylic acid applied through rooting medium on drought tolerance of wheat Pakistan, J. of Bot., 38(4): 1127-1136.

Yavas, I. and A. Unay (2016). Effect of Zinc and salicylic acid on wheat under drought stress. Journal of Animal \& Plant Sciences, Vol. 26 Issue 4:1012-1018. 
تأثير الرى المنقوص و الرش الورقى بحامض السلسيلك و سيليكات البوتاسيوم على أداء محصول البصل

أحمد إسماعيل عبد العال(1) ، عبد الهادى خميس عبد الحليم(2) ، أشرف النماس(3)

(1) قسم بحوث الاراضي الجيرية و الرملية - معهد بحوث الاراضي و المياهو البيئة - مركز البحوث الزراعية

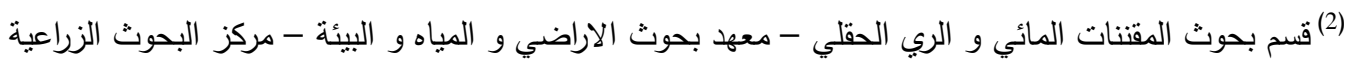

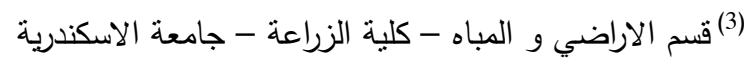

الملخص العريي

أجريت تجربة حقلية فى الموسم الزراعى الثتوى 2011-2012 و 2012-2013 فى المزرعة البحثية بالبستان بجنوب التحرير لدراسة تأثنير نقص الماء والرش الورقى بحامض السيلسيلكو سيليكات البوتاسيوم بتركيزين

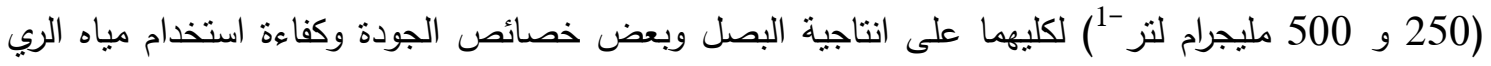
المضافة. كان التصميم الإحصائى المستخدم القطع المنشقة مرة واحدة وكانت المعاملات كالتالى:

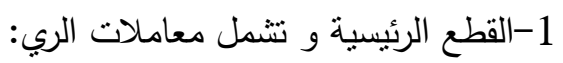

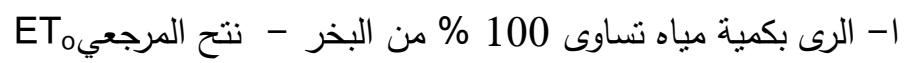

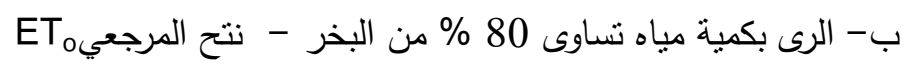

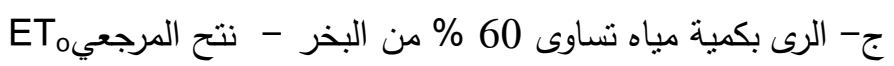
2- القطع التحت رئيسية ونتشمل معاملات:

ا- الرش الورقى حامض السيلسيلك بتركيز 250 مليجرام لتز ${ }^{1-}{ }^{1-}{ }^{-1}$ (SA

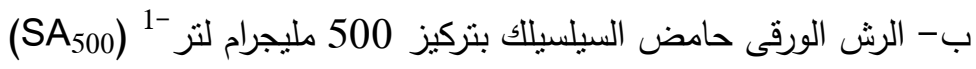

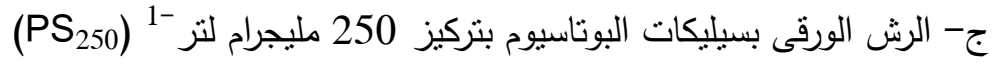

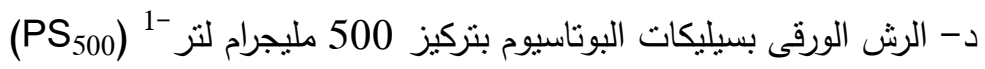
يمكن تلخيص النتائج المتحصل عليها كالاتي:

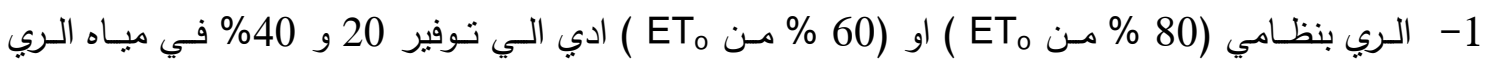

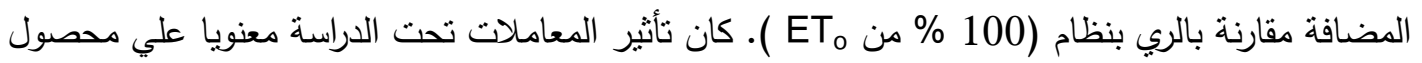
البصل وقطر ووزن البصلة في كلا الموسمين، وسجلت القيم الاعلي لتلك الصفات مع بالري بنظام (100 ب باتير

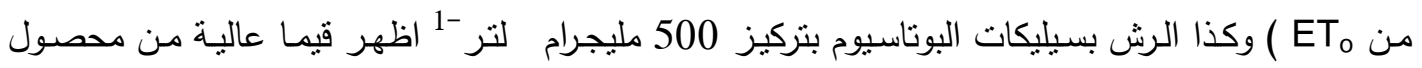

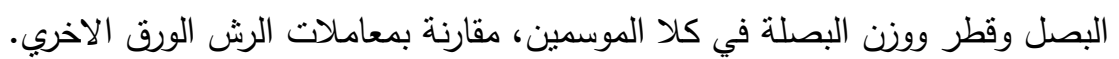

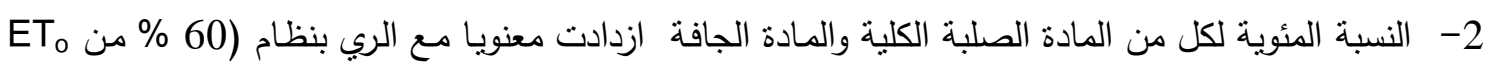

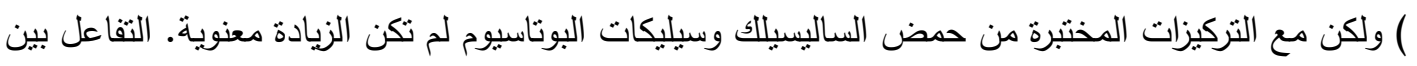




\section{Abd El-All, et al.,}

ش ش حض الساليسيلك بتركيز 250 مليجرام لتر -1 والري بنظام (60 \% من ETo ). اظهر قيما عالية من الصفات سالفة الذكر .

3- اتجهت قيم كفاءة استخدام مياه الري المضافة (IWUE) الي الزيادة مع نقص معدل الري والعكس صحيح ،

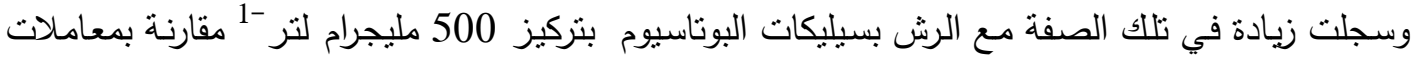

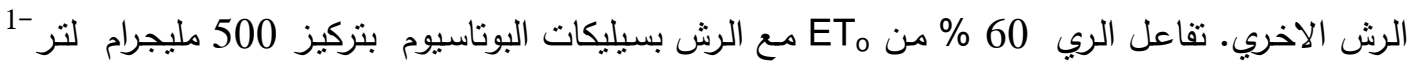
اعلي قيم (IWUE) في موسمي الدراسة.

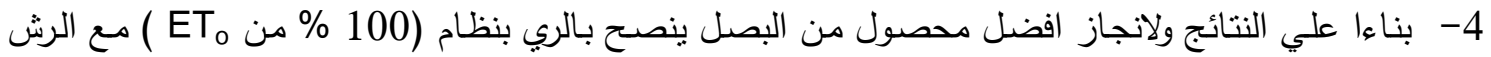

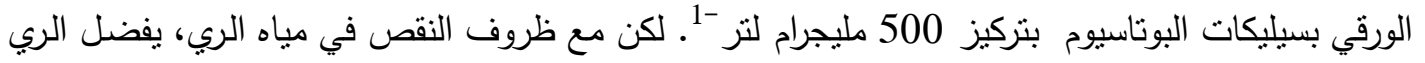

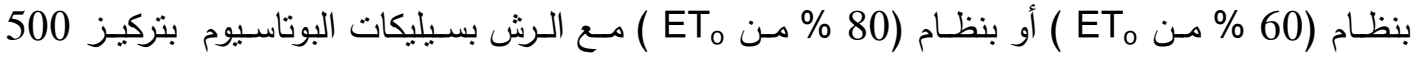
مليجرام لتر -1 للحصول علي قيم مقبولة لمحصول البصل ذو جودة عالية مع توفير 20 - 40\% من من مئاه الري المضافة. 